\title{
Müzik ve Siyaset: Duygu ve Düşüncenin Etkileşimsel İşbirliği
}

\author{
İRFAN PAÇACI* \\ irfanpacaci@hotmail.com \\ ORCID-ID: 0000-0002-7142-6709
}

Öz: İnsanlığın ortak kültür mirasını oluşturan duygu ve düşüncenin "paylaşımcı ve etkileşimsel işbirliği”"nin ortaya çıktığı alanlardan biri olarak müzik; barış ve özgürlü̈̆̈̈̈n birleştiği bir faaliyet alanıdır. Ancak müzik bu işlevin de ötesine geçen işlevlere sahiptir. Uyum, işbirliği, ahenk, uzlaşı, aklın ve duygunun işbirliği, ortak değerleri yaşatmanın, madde ve mananın birlikte üretim yaptı̆̆ı, söz ve ezgi olarak somutlaştığı bir faaliyet alanıdır. Bu özellikleri taşıyan diğer bir toplumsal faaliyet olan siyaset ile ortak özelliklere sahiptir. Siyaset hem birlikteliği hem de farklı olmayı ortaya koymanın mekanizmalarını ve değerlerini temsil etmektedir. Çağdaş devletlerde demokratik toplumun gerekleri arasında yer alan müzik ve siyaset kültürel bir gösterge oluşturmanın ötesinde toplumun gelişiminde iki önemli katalizör olma potansiyeline sahiptir. Her ikisi de işbirliği ve uyumun işlevsel ve kültürel malzemelerinin üretildiği ve toplumsal hayata kazandırıldığı alanlardır. Bu çalışmanın temel hipotezini; müzik ve siyasetin toplumu özgürlük ile besledikleri oranda demokrasinin yaşamasına ve gelişmesine pozitif katkı sağlayacakları yaklaşımı oluşturmaktadır.

Anahtar kelimeler: Müzik, Siyaset, Demokrasi, Etkileşimsel işbirliği.

\section{Giriş}

Yaratılanlar içinde duygu ve düşüncenin "aklın” yönetiminde koordineli olarak işbirliği yaptığı tek yaratık insandır. İnsanın bu özelliğinin tipik olarak ortaya çıktığı alanlardan biri müzik diğer de siyasettir.Tarihten günümüze insan yaşamının değişiminde etkin bir rol oynayan müziğin modern toplum yaşamında sosyo-politik etkileşimin kurulmasındaki rolü ve bunu nasıl gerçekleştirdiği siyasal kurumların oynadığı işlev-rol kadar önemlidir.

Çağdaş katılımcı ve müzakereci demokrasilerde siyaset kadar müziğin de toplumdaki siyasal değerlerin dağılım ve mobilizasyonun da taşıdığı değer en az görünen parametreler kadar önemlidir.

* Doç. Dr. Marmara Üniversitesi, İletişim Fakültesi, Gazetecilik Bölümü. 
Kültür değerlerinin politik organizasyonuna ilişkin olarak belirleyici kodları açık bir biçimde görünmeyen bu dinamiğin ölçümlenmesinde ve bir toplumun sosyo-kültürel yapısını yansıtmadaki etkinliğinin sağladığı katma değerin payı önemli bir gösterge sayılmalidir.

Özgürlük ile kültür-sanat ve müzik arasında kurulan parametrik ilişki küresel kapitalist düzenin kendini yeniden düzenlediği üretim-tüketim ve bölüşüm sistemi ile popüler kültür retoriğinin yansıması olarak her şeyden önce görsel ve işitsel özelliktedir. Dolayısıyla küresel düzeyde iletişim sistemi ve medya düzeni bu yapının stratejik organizasyonunu sağlayan yapı olup, ulusal ve yerel ölçekteki düzenler bu majör sistematiğin içinde yer almaktadırlar.

Demokratik toplumlarda politika kurumunun siyasal kültürün gelişimine sağladığ ölçümlenebilen katkının yanında başkaca önemli destek araçları ve alanlarının da olduğu benimsenerek, işlevsel hale getirilmelidir.

Sanat ve özellikle müzik, toplumun üyesi olan bireyin toplumsal kurumlar içinde kendini özgür biçimde anlatabildiği, toplumun gelecekle arasında köprü kurduğu değişime ve dönüşüme olanak sağlayan "özgürleşme" ve "kendini ifade etme" yöntemidir. Bu yöntemin toplumsal etkileşimi sağlayacak şekilde uygulanabilmesi, "müzikte işbirliğini” zorunlu kılmaktadır.

Çağdaş katılımcı demokrasilerde politika ve müzik, toplumun gelişiminde işbirliği ve uyumun işlevsel ve kültürel malzemelerinin üretildiği ve toplumsal hayata kazandırıldığı alanlardır. Birinin yokluğu diğerinin eksikliği olup eksik olan yapılar hiçbir zaman tam ve mükemmel sistemlerin sonuçlarına ulaşamazlar.

İnsanlığın kültür üretim alanı olan müzik duygu ve düşüncenin "paylaşımcı ve etkileşimsel işbirliği”nin ortaya çıktığı alanlardan biri olarak dikkat çekmektedir. Barış ve özgürlük işbirliğinin, uyum ortak hedeflerin, adil paylaşım uzlaşı ve ahengin, aklın ve duygunun işbirliği ortak mantık kurmanın yolu olarak; müzik ve siyaseti adeta bu değer ve normları kurmanın ikiz alanı olarak kodlamaktadır. Kısaca müzikte ve siyasette ortaya çıkan bu özellikler bu iki alanı bir araya getiren uzlaşma bileşkesine dönüştüren özelliklere sahiptir. Bu durum bir hipoteze çevrilerek müzikte ve siyasette; duygu ve düşüncenin "paylaşımcı ve etkileşimsel işbirliği”nin ikiz alan teorisi kurmamıza olanak sağlamıştır.

\section{İnsanlığın Kültüir Üretim Alanı: Müzik}

Toplumsal hayatın başlamasıyla birlikte iletişim insan ilişkilerinin kurumsal biçime dönüşmesinin, dilin birçok alanda anahtar bir kurgusal matematiğinin oluşturulmasına yol açtığı görülmektedir. Alfabe, haberleşmede, müzikte, fizik bilimler ve elektronikte birer devre ve taşıyıcı, iletici görevi görmüştür. Nitekim, "Dilin ve müziğin sesleri, aynı kaynaktan çıkmış, zaman içinde farklı yönlere doğru evrilmiş ve birbirinin yerini dolduramayacak iki ayrı sistem oluşturmuştur."

1 Özay Önal, “Ses, Dil ve Müzik”, Dil Dergisi, 155 (2012), s.21. 
Abraham Maslow'un İhtiyaç Hiyerarşisi Teorisi, insanların neden farklı zamanlarda farklı gereksinimlerini ön plana çıkardıklarını araştırmış ve bir ihtiyaç hiyerarşisi teorisi geliştirmiştir. Bu teoriye göre, insanın gereksinimleri l'den 5’e doğru önem sırasıyla belirtilmiştir. İlk sırada fiziksel gereksinimler (yiyecek, su, barınma gibi) yer alırken son sırada ise kişisel ilgileri/fikirleri/idealleri ortaya koyma gereksinimi (kendini geliştirme, kişisel yaşamı zenginleştirme, kişisel hedefleri gerçekleştirme gibi) bulunmaktadir.

21. yüzyılda ortaya çıkan değişim paradigması otantik ve küresel dinamiklerinin yeniden biçimlendirmekte müzik olgusu da bu gelişmelerden etkilenmektedir.

Müzik tarihinde müzik çeşitlerinin kültürel farklılıkların zenginliğini yansıtma yanında insanlığın ortak kültür birikimini temsil etmesine yönelik ortak düşüncenin somutlaştığı bir dönem yaşanmaktadır. Dolayısıyla hem birey hem de toplum açısından "müzik" gerçekliği günümüz dünyasında sosyal yaşamın sağlıklı ve doğal akışı için önem taşımakta, bu durum müzik sosyologları ve müzik psikologları tarafindan da vurgulanmaktadır.

Kitle iletişiminde meydana gelen hızlı değişim ile birlikte radyo, televizyon, plak ve film endüstrisinin kazandırdığı ivmeyle müzik ürünleri dünyanın her tarafına hızla yayılmaktadır. Küreselleşme ve ticarileşme ile "Müziğin mal olması ve pazar yapısının gelişmesiyle birlikte müzik yazan, müziği söyleyen ve müziği dinleyen arasındaki ilişkilerde değişmiştir. Müzik serbest pazarda önemli bir konumda oturmaktadır."

Müzikologlar yaklaşık beş bin yıllık geçmişe sahip bulunan Türk müzik kültürünün küreselleşme politikaları ekseninde yeniden yapılandırılarak Batı kültür ve değerlerini taşımaya odaklanan "popüler müziğin" etkileşiminde tüketim toplumu üretmeyi öngören bir seyir göstermektedir.

Temelleri sağlam atılmış bir toplumda müzik; yaşam kalitesini de olabildiğince yükseltecek toplumsal yaşam kalitesine pozitif katkı sağlayacak bir etkendir.

Frankfurt Okulu'nun öncülerinden olan Theodor Adorno; 1941'de yayımlanan "On Popular Music” adlı önemli makalesinde ${ }^{3}$ popüler müzik ile ilgili olarak pop müzik standartlaştırıldığını ve resmi müzik kültürü, müzikal dilin tüm tonik ilişkilerini üstyapıda taşıyarak temsil eder. Müziğin; popüler ya da başka türler aracılığıyla, bireyden yola çıkarak toplumsal yaşamı etkileyecek yönde kullanımına dair örnekler de mevcuttur. ${ }^{4}$ Örneğin Barok müziği, istikrar, düzen, tahmin edilebilirlik, emniyet hisleri yaratır. Çalışma için de zihinsel açıdan uyarıcı bir ortam yaratır. Haydn ve Mozart'ı dinlemek; konsantrasyon, hafıza ve üç boyutlu algıyı geliştirebilir. ${ }^{5}$

2 Ersan Çiftçi, “Popular Culture, Populer Music and Music Education”, Erzincan Eğitim Fakültesi Dergisi, 12/2 (2010), s.159.

3 Theodor W. Adorno, “On Popular Music", Studies in Philosophy and Social Science, New York: Institute of Social Research, 9 (1941), s.17-48.

4 Don Campbell, Mozart Etkisi, çev. Feryal Çubukçu, İstanbul: Kuraldıșı Yayıncılık, 2002, s.101-103.

5 Bkz. Cemal Yurga, 20. Yüzyılda Türkiye’de Popüler Müzikler, Ankara: Pegema Yayıncılık, 2002. 


\section{Müzikte ve Siyasette İşbirliğinin Yükselttiği İki Değer: Barış ve Özgürlük}

Genel bir tanımlama ile müzik, sesin biçim ve anlamlı titreşimler kazanmış hâli ya da sesin ve sessizliğin belirli bir zaman aralığında ifade edildiği sanatsal bir formdur. Müzik, kelimelerle anlatılamayan duygu ve düşüncelerin seslerle anlatılması sanatıdır. Bu anlamıyla, biçim ve titreşim içeren bir ses oluşumunun müzik olarak kabul görmesi için dinleyenlerde duygulara yönelik etkileşim yapması da beklenmektedir. ${ }^{6}$ $\mathrm{Bu}$ etkinin güçlü biçimde oluşturulabilmesi müziğin uygulamasında kullanılan araç ve öğelerin işbirliği ve uyumu ile ilgili bir durumdur.

Müzik, insan ya da çalgı seslerinin, belli bir biçimsel güzellik ya da duygusal mimari yaratacak biçimde düzenlenerek bir araya getirilmesini içeren sanat dalıdır. Bu düzenleme kültürlere göre belirlenmiş ayrı melodi ve ritim (Batı müziğinde armoni) standartlarına uygun olarak ifade deseni ve ritim düzeni kurarak gerçekleştirilmektedir. Bağımsız ve özgür her toplumsal kültür ayrı bir müzik coğrafyası ve sistemi oluşturmaktadır. Uygarlığın bir alt bölümünü oluşturan dil, kültür, inanç, değerler sistemi ve sanat üretileri yanında müzik ayrı ve özel bir alt sistematik meydana getirmektedir.

Bir faaliyetin amacına ulaşabilmesi için; maddi ve manevi bütün faktörlerin planlama ve organizasyon süreci içinde yer alması ve koordineli olarak yönetilmesi gerekmektedir. Hedeflenen amaçların etkili ve verimli bir şekilde gerçekleştirilmesi ise onları oluşturan varlıklara değer kazandırılması ile ilgili işlemlerinin gerçekleştirildiği süreçleri içermektedir. Yönetim süreci olarak tanımlanan bu aşamalarda planlama, örgütleme, yöneltme, koordinasyon ve kontrol işlevlerine de olanak sağlayacak eylemin ortaya konulması gerekir ki, bu da ancak "işbirliği” ile somutluk kazanmaktadır.

Nitelikli ve kaliteli insan ve onun çevresini oluşturan, iş süreçleri ve onları kapsayacak kurumlar, ancak "işbirliği” ile eğitilip, üretilip yönetildikleri ölçüde geleceği aydınlatabilirler. İşbirliği, aynı zamanda dayanışma ve paylaşma gibi insandaki yüksek karaktere dayalı olarak somutlaşan "erdeme" işaret eden değerleri temsil etmektedir. Müzik; ruh ve duygunun en üst seviyede buluşmasını ve akıl ile "işbirliğini" sağlayacak olan doğal ve insani iklimi oluşturmaktadır.

Siyaset, tarihsel süreçlere bağlı olarak toplumsal yaşamın özünde yer alan ve evrimsel dönüşümlerle değişerek yenilenen maddi ve manevi değerlerin "paylaşım ve bölüşümü” ile ilgili faaliyetlerin bütünüdür.

Günümüzde "siyaset" kavramı üzerinde çok değişik tanımlamalar yapılmıştır. Bu tanımlardan birine göre siyaset, "toplumda farklı istek ve çıkarlara sahip kişiler arasında meydana gelen bir çatışma ve bölüşüm mücadelesidir". Mücadele sebebi ise kıt kaynakların bölüşümü ve kullanımında etkin olmaktır. Çatışmanın hedefi iktidara sahip olmaktır.

Siyaseti bir hizmet aracı olarak gören diğer bir tanıma göre siyaset, kişisel çıkarlar

6 Müzik, Erişim 27 Ocak, 2018, http://tr.wikipedia.org/wiki/M\%C3\%BCzik.

7 Münci Kapani, Politika Bilimine Giriş, Ankara: Bilgi Yayınevi, 2008, s.17. 
yerine toplumun genel çıkarlarını gözetmek ve paylaşımdan tüm toplum bireylerini eşit oranda faydalandırmak amacıyla hareket eden, toplumun çıkarlarının ön planda olduğu ve korunduğu bir yapıdır. ${ }^{8}$

Diğer yandan siyasetin, hem bir çatışma hem de uzlaşma olduğu öne sürülmektedir. Çatışmanın ve uzlaşmanın motoru durumunda olan siyasetin nasıl yapıldığı ve yönetildiği hukuk-siyaset ekseninde yürürlükte ki "hukuk" ile de doğrudan ilgili olduğu anlaşılmaktadır. Bu değerlendirme siyasal hukuk olarak ifade edilen "anayasa” ve anayasada kurulan sistemin çözümlenmesini gerekli kılmaktadır.

Siyasetin denge üzerine kurularak işleyen bir mekanizma olduğu ve tarafların uyumu ile istikrarın düzenin koşulu olduğu savı demokratik rejimlerin çatışmayı değil uzlaşıyı öngördüğü tezi üzerine kurulmaktadır.

İnsan içinde yer aldığı çevreden hem etkilenir hem de etkiler, toplumsal hayatın üretim biçimine, teknolojiye ve bilimsel araştırmalara bağlı gelişimi insanın düşünsel ve algısal kapasitesinin ve yeteneğini de gelişmesine olanak sağlayarak, düşünce ve inançta olduğu gibi zevkler, tercihler ve beklentilerin değişerek çeşitlenmesi ile müzikteki algılarda da farklılaşmıştır. Toplumsal düzen ve kültür içinde gelişen "Müziksel algılama süreci; beyne gelen anlamlı frekansların, daha önceden öğrenilmiş anlamlı kalıplar içinde aranıp, süzgeçten geçirilip anlamlandırılması yani bir müziğe dönüşmesi ile ilgilidir."

Bir toplumdaki algılama kapasitesi ve yeteneği diğer bir çok faktör yanında, kültür altyapısı içinde müzik aracılığı ile dil, kültür, ses, iletişim yeteneği gibi bileşenlerin işlenip yorumlanması sonucunda düşünsel ve duygusal bakımdan anlamlı hale gelmekte ve zenginleşmektedir. Böylece "Müziğin bireyler üzerinde öznel estetik değerler oluşturmasının yanı sıra, sosyal hayatın şekillendirilmesi, ülkelerin kültürel değerlerinin benimsenmesi, tanınması ve yayılması konusunda da büyük bir öneme sahip olduğu bilinmektedir. Müzik beğenisi bireyin yaşadığı toplum içerisinde var olan sosyal etki ve kültürel süreçler içerisinde şekillenir. Dolayısıyla insanların müzik beğenileri gibi çalgı beğenilerini de oluşturan zeminde toplum ve kültürün etkisi mutlaktır. Kültür insan yapısıdır ve insanın yaptı̆̆g her şey kültürün bir parçasıdır. İnsan üreticidir, yaratıcıdır ve tüm sosyo-kültürel sistem insanın ürünüdür."10

Toplumsal etkileri yanında müziğin birey açısından gerek sosyo-kültürel gerekse de gelişimi açısından olumlu katkıları bulunmaktadır. Özellikle "Müziğin kişisel işlevleri; müziğin, kişi üzerindeki işgörülerini kapsamaktadır. Bu işgörüler, bireyin sağlıklı ve dengeli, kendine özgü bir kimlik ve kişilik geliştirebilmesinde önemli rol oynar." ${ }^{11}$

Tarihsel süreç içinde müzik, her dönem de siyaset, ekonomi ve din kadar toplumla ve

8 Abdullah Özkan, Siyasal İletişim, İstanbul: Nesil Yayınları, 2004, s.25.

9 Nilgün Sazak, "Müziksel Algılamanın Temel Boyutları”, Uluslararası İnsan Bilimleri Dergisi, 5/1 (2008), s.6.

10 Tekin Doğan ve Barış Erdal, "Senin Favori Çalgın Hangisi? Çalgı Tercihini Etkileyen Demografik ve SosyoKültürel Faktörler Üzerine Bir Araştırma”, Journal of Human Sciences, 13 / 3 (2016), s.6053.

11 Tuba Kılıç, "Müziğin Kişisel, Toplumsal, Ulusal ve Uluslararası İşlevlerinin Müzik Eğitimine Etkileri”, 38. ICANAS (International Congress of Asian and North African Studies - Uluslararası Asya ve Kuzey Afrika Çalıșmaları Kongresi, Ankara, Eylül 10-15, 2007), Atatürk Kültür Dil ve Tarih Yüksek Kurumu Yayınları: 9, I. Cilt, 2009, s.468. 
toplumsal yaşamın istikrarı ve kalitesi ile ilgili bir unsur olagelmiştir.

Müziğin kitleler üzerindeki etkisi her dönem de iktidar yapılarının dikkatini çekmiş ve yönetme erkini yerine getirirken bu özelliklerinden dolayı müzikten bir kontrol aracı olarak barışta olduğu kadar savaşta da yararlanılmıştır. Eski dönemlerden itibaren müzik ile özellikle ilahî dinler arasındaki ilişki, toplumsal düzenin bir parçası olmuş, "Dinî ögeler içeren müzik türlerinden belki de en popüler olanı Blues olmuştur." ${ }^{2}$ İslami anlayış içinde ilahiler, mehter marşları, semai, deyiş, ağıt ve mersiyeler ile müzik ile ritüeller, dua, zikir ve ibadet şekillerinin kurulduğu görülmektedir. Müzik ile inanç boyutunda ilginin, tasavvuf ehli tarafından bir usule dönüştürülmüş, sufilik ve tarikatlar ile Bektaşi tekkelerinin temel karakteristiği hâline gelmiştir. ${ }^{13}$

\section{Müzikte ve Siyasette Küreselleşmenin Etkisi: Kültürel Bozulmanın Formülü}

Kamusal ya da özel yaşam alanlarında çeşitli biçimlerde ve kurallar kümesi içinde farklı fikirler, çıkarlar, beklentiler birbirlerine üstünlük sağlamak için çatışırken, siyasetin aslında toplumsal düzenin kurulup işletilmesi ve sürdürülmesinde toplumsal huzur ve barışın sağlanması için bir araç olduğu gözlemlenmektedir. Birbirinden siyasal kültür ve ekonomik gelişmişlik kriterleri bakımından farklı olan her toplumsal düzende insanlar ortak kurallara bağlı olarak, barış ve huzur içinde yaşamak için çaba sarf ederler. Bu insani güdü siyaseti harekete geçiren temel motivasyon olup, potansiyel olarak her tür toplumda mevcuttur. Kısaca siyaset toplumsal uzlaşma arac1 olarak tanımlanabilir.

Anayasa ve siyaset bilimi uzmanı Maurice Duvarger'in anlatımı ile iktidar olgusu; "emir verme", "yönetme", "insanların davranışlarını kontrol etme" hattı üzerinde oluşurken demokratik zihniyetin geliştiği fikir ortamında "yönetilenlerin” rolü, iktidar karşısında aldıkları tavırlar ve iktidarı etkileme ve hatta bazen zorlama yeteneği, siyasal iktidar tanımının alanına aslî bir ögeyi de dahil etmeye başlamıştır. Bu, iktidar ilişkisinin ${ }^{14}$ tek taraflı değil, karşılıklı etkileşime dayalı olduğu gerçeğidir. Dolayısıyla politikanın amacı toplumdaki değerlerin dağıtımı olup, toplumda iktidar mücadelesi "dengeyi” oluşturmak üzere işletildiği sürece demokratik mekanizmaların gücü ve etkisi giderek artacaktır.

Siyasetin kuruluş, işleyiş ve yönetimi “denge” esaslı olduğu sürece ve ya ölçüde politik faaliyetler ve siyasal kurumlar demokrasiyi güçlendirecektir.

Denge odaklı ve demokratik bir siyasal sistemin mimarisi ancak asgari bir anlaşma ve barış ortamı içinde ve politik kurum ve aktörlerin faaliyetlerini serbestçe yürütebildiği koşullarda gerçekleştirilebilir.

Hukuk yönetimin bir aracı olma yanında politiğin hukukileştirilmesi ile ilgili bir

12 Feyzan M. Göher, “Müziğin Toplumsal İşlevi Müzik, Siyaset, Din ve Ekonomi”, 38. ICANAS (International Congress of Asian and North African Studies - Uluslararası Asya ve Kuzey Afrika Çalışmaları Kongresi’nde Sunulan Bildiri, Ankara, Eylül 10-15, 2007), Atatürk Kültür Dil ve Tarih Yüksek Kurumu Yayınları: 9, I. Cilt, 2009, s.311

13Göher, "Müziğin Toplumsal İșlevi Müzik, Siyaset, Din ve Ekonomi”, s.311.

14 Bkz. Kapani, Politika Bilimine Giriş, s.19-22. 
sürecin de somut çıtısıdır. Siyasal iktidar elde edildikten sonra iktidarın üstün gücü sayesinde kural ve yöntemler oluşturularak iktidar, üretilen hukuk aracılığı ile yönetilenler nezdinde meşru bir yapıya kavuşmaktadır. Böylece iktidar ilişkilerini de kapsayan ve geniş bir alanda gerçekleșen politika (yapma) süreci esasında "kanunun yazılış biçiminden, imkan verilen eylem ve işlemlerin niteliğine kadar her şey politiktir." ${ }^{15}$ yargısını oluşturmaktadır. Güç kullanma tekeline sahip olan devletin hukuk yaratma sürecinde de politik sürecin işlediği bir işlevi (“dengeyi” kurma) yerine getirmekte olduğu görülmektedir.

Devlet olgusu aslında siyasal iktidar ile gerçeklik kazanarak somut hale gelmektedir. Hukuk aracılığı ile devletin kurumsal kimliğini kazanması, iktidarın da bu çerçevede "hukukun üstünlüğü" ilkesine uygun olarak, meşruiyet sağlamasının zeminini oluşturmaktadır. Esasen, "devlet iktidarın içindedir. Çünkü iktidar olmadan, otoritenin

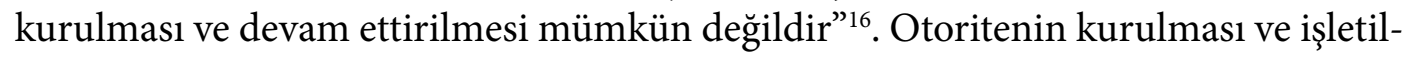
mesinde meşruiyet unsuru kilit rol oynamaktadır.

Otoritenin meşruiyeti ise toplumsal kabul ve bu kabulün hukukileştirilmesine bağlı olup, devletin tekelinde bulunan "kuvvet uygulama” üstünlüğü ancak bu şekilde siyasal iktidar bakımından uygulanabilir nitelik kazanabilmektedir.

Kapitalist düzenin üretim yapısı ve siyasal rejimleri üzerinde sağladığı değişim, kültür ve sanatta da gerçekleşmiştir. Özgürlük ile müzik arasında kurulan ilişki kapitalist sistemim üzerine inşa edildiği popüler kültür söyleminin yansımasıdır. Müzik alanında bu etki; “...bireylere gerçek yaşamda bulamadıkları doyumları sağlarken, bu gereksinimlerinin toplumun var olan koşullarından ya da kısaca efendi-köle, egemen-bağımlı ilişkisinden kaynaklandığını söylemez; tam tersine, bu ilişkiyi olduğu gibi benimsetmeye çalışır. Ama müzik, bu işlevini herkesin anlayacağ yerine getirmekten çok, var olan toplumsal yapıda temel olan yabancılaşmayı, bu yabancılaşma içinde bulunan insanın algılayamayacağı bir düzeyde benimsetir. Nitekim popüler müzik, sıradan ve tek örnekleștirici etkisiyle, etkin ve kalıcı bir dinleme gerektiren nitelikli müziğe göre yapay bir eğlendiricilik sergiler; sanat alanında metalaşmayı olumlayan, hatta bunu davet eden bir müzik türü olarak değişimi yaratacak sınıfın henüz ortaya çıkmadığı bir dönemdir." ${ }^{17}$ Böylece, küreselleşme süreci ile birlikte kültür gibi müzik de tüketime dayalı kitle kültürüne evrilerek yeni bir biçim kazanarak, endüstriye dönüşmüştür. Bu değişimi hızlandıran ve yapısallaştıran etki ise medya tarafından üretmektedir.

Küresel tekelleşme ve onun lokomotifi olan çok uluslu şirketlerin sektörel düzenlemeler ile müzik ekonomisini de yeniden yapılandırmakta olduğu görülmektedir. Bu kapsamda olmak üzere; “Ticaret dünyasında, insanlar müzik endüstrisi kelimelerini kayıt endüstrisi olarak anmaya başlamış, 2000'li yıllarla birlikte dünya müzik pazarı üç büyük şirket ve marka tarafından kontrol altına alınmıştır. Bunlar; Fransız kuru-

15 Dilan Mızrak ve Özgür Temiz, "Hukuk ve Politika Türkiye’de Yaşanan Olağanüstü Dönemlerin Edebiyat Eserleri Işığında İncelenmesi”, Ankara Barosu Dergisi, 67/2 (2009), s.81.

16 David Daiches Raphael, Problems of Political Philosophy, London: Macmillan Education Ltd., 1990, s.15.

17 Filiz Aydoğan, "Popüler Kültür ve Popüler Müzik”, İstanbul Üniversitesi Illetişim Fakültesi Dergisi, 20 (2004), s.211-212. 
luşu olan Universal Music Group, Japon kuruluşu Sony Music Entertainment ve A. B.D. kuruluşu Warner Music Group'tur. Diğer kuruluşlar ve markalar ise genellikle bu kuruluşlara bağımlı çalışmışlardır.” ${ }^{18}$

Günümüzde dijital platformlarda gerçekleşmekte olan müzik üretiminin değişim trendinde “....1880’lerin sonunda ticari olarak yayımlanan müzikal performansların fonograf kayıtları, 1920’lerde yayın hayatına başlayan ve oldukça geniş kitlelere ulaşabilen radyo yayınları ile müziğin işitilmesini kökten değiştirmiştir." ${ }^{19}$

Ekonomi politiği yöneten ve teknolojiyi üreten siyasal güçler, popüler kültür ve küreselleşme projeleri ile yeni dünya düzeninin tüketim toplumunu inşa etmek üzere; tek tip kültür kalıpları ve anlayışını oluşturmak için giyim kuşam, yeme içme ve sosyal hayat tarzında "Batı-Hristiyan değer ve kültür formlarını" özellikle medya, müzik ve sanat araçları aracılığı ile toplumların günlük yaşamının bir parçası haline getirmektedir.

Bir toplumda siyaset, din ve ekonomi üçlüsünün toplumu düzenlemek üzere koordineli olan işbirliğinin, siyasi kurumlar ve o toplumu oluşturan tüm kültürel değişkenler tarafindan diğer unsurlara ek olarak düşünülmektedir.

Siyasal sistemlerin yönetim modelinin işleyiş simülasyonu çerçevesinde, hangi tip sanatın üretileceği, sanatın rolü ve pozisyonu, müziğin hangi işlevlerinden yararlanılacağı toplumun müziği nasıl etkilediği ve müzikten nasıl etkilendiği bağlamında planlanıp değerlendirilmektedir. Nitekim, "Müzik, her ne şekilde adlandırılırsa adlandırılsın tarihler, değerler, uzlaşımlar, kurumlar ve onları bağrına basan teknolojilerle anlam kazanır." ${ }^{20}$

\section{Müzikte ve Siyasette Ortak Hedefleri Sağlayan Araçlar: İşbirliği ve Uyum}

Ekonomi de temel varsayım olarak öne sürülen; "ihtiyaçlar sonsuz olurken kaynakların sınırlı olması"21 (kıt kaynaklar) kuramı karşısında, talebin rasyonel biçimde karşılanması gerekmektedir. Bu durum da ise üretim faktörlerinin sağlanması ve bunların doğru biçimde yönetilmesini gerektirmektedir. Toplumsal bir varlık olan insanın ihtiyaç duyduğu gereksinmelerden biri de müziktir. Müzik kendine özgü dili, yapısı ve anlatım öğeleriyle insanın duygu ve düşüncelerine seslenerek ${ }^{22}$ toplumsal kimlik tanımını oluşturan kültürel bir değere dönüşmektedir. Böylece, müzik; dinlemek, dinlenmek ve toplumsal hayat ile ilgili faaliyetleri gerçekleştirmek açısından gerekli

18 Hasan Arapgirlioğlu, “Dünyada ve Türkiyede Müzik Endüstrisinin Dünü, Bugünü ve Yarını”, içinde Yaratıcı Endüstriler Uluslararası Tasarım Sempozyumu (01-02 Haziran 2016) Bildiriler Kitabı, ed. Mehmet Emin Kahraman, İstanbul: Yıldız Teknik Üniversitesi Basım-Yayın Merkezi, 2016, s.3.

19 Arapgirlioğlu, “Dünyada ve Türkiyede Müzik Endüstrisinin Dünü, Bugünü ve Yarını”, s.4.

20 Ali Haydar Timisi, "Müzik Nedir”, Erişim 17Ăgustos, 2018, http://www.timisi.com/blog/2017/10/30/muziknedir/

21 Bkz. Adam Smith’in 1776 yılında yazdığı "Ulusların Zenginliği” isimli çalışması ile oluşturduğu kuramlar Kapitalist sistemin özünü oluşturan klasik iktisadın temelini kurmuştur. Smith bu kitabında, dünyada serbest ticaretin gerek ülkelerin ve gerekse dünya refahının artması bakımından çok daha yararlı olacağını savunmuştur. Adam Smith, Milletlerin Zenginliği, çev. Haldun Derin, İstanbul: İş Bankası Kültür Yayınları, 2016.

22 Neslihan Karamızrak, “Ses ve Müziğin Organları İyileştirici Etkisi”, Koşuyolu Heart Journal, 2014, 17(1), s.54. 
olduğu üzere ${ }^{23}$ sağlıklı ve dengeli bir yaşamın sürdürülmesinde, insani yaşam kalitesinin unsurları arasında değerlendirilebilir. ${ }^{24}$ Müzik, eski zamanlardan beri insanlar üzerinde önemli bir yer işgal etmiştir. İnsanlar üzüntülerini, sevinçlerini, kahramanlıklarını, heyecanlarını, sevgilerini vb. çoğunlukla müzik sanatını kullanarak ifade etmeye çalışmışlardır. ${ }^{25}$

Not edelim gözlemlenen o dur ki, psikoterapi alanında Türk müziği gittikçe önem kazanmaktadır. Çeşitli araştırmalar ve uluslararası bilimsel toplantılarda dile getirilen görüş ve sunulan bildiriler bu düşünceyi ortaya konulmaktadır. Nitekim 1993 yılında İstanbul'da düzenlenmiş olan "II. Uluslararası Müzikoterapi ve Etnomüzikoloji” sempozyumunda bu yönde bildiriler sunulmuştur.

Orta Asya Türk Kültüründe daha sonra da 9.yy’da Türk-İslam Dünyasındaki hastalara yönelik olarak müzikoterapi faaliyetlerinin uygulandığ 1 tespit edilmiştir. Özellikle Selçuklu ve Osmanlı hekimlerinin değişik makam ve enstrümanlardan yararlanarak müzik terapisi ile hastalara fayda sağladığı anlaşılmaktadır. Günümüzde ise müzik sağlık açısından tedavi edici etkisi yanında stresle mücadelede, hayvan ve bitkilerin terapisine kadar çeşitli alanlarda verimi ve üretimi arttırmak üzere de uygulanabilmektedir. $^{26}$

İnsanın duygu, düşünce ve ruhsal doyumuna yönelik olarak gerçekleştirilen bir faaliyet olarak müzik, üretim ve bu üretime katılan faktörlerin belirlenen amaçlara ulaşmak için; planlama, organizasyon, yöneltme koordinasyon ve kontrolü gerektiren yönetsel bir sürecin ${ }^{27}$ izlenmesini gerektirmektedir.

Sağlıklı, mutlu ve refaha erişen toplum, maddi değerler yanında istikrarın sürdürülebilmesi için, destekleyici, geliştirici ve koruyucu faktörlere de sahip donanımlı organizasyonlardır. Bu tür organizasyonlarda sağlam ve dengeli bir gelişim sağlanmasının koşullarından biri de tedavi edici mekanizmaların sistemde yer almasıdır. "Müzik terapi, bireylerin fiziksel, psikolojik, sosyal ve zihinsel ihtiyaçlarını karşıla-

23 Müzik, günümüze kadar çeşitli nedenlerden dolayı şifa sağlama bakımından sağlık ile ilgili ortamlarında kullanılmış. ses terapisinin birçok hastalığın tedavisinde etkili olduğu saptanmıştır. Bkz. Karamızrak, "Ses ve Müziğin Organları İyileştirici Etkisi”, s.55.

24 Birleşmiş Milletler Kalkınma Programı (United Nations Development Programme-UNDP) İnsani Kalkınma Endeksini (Human Development Index-HDI) geliştirerek, yıllık İnsani Kalkınma Raporlarında (Human Development Report-HDR) her yıl yayınlamaya başlamıştır. "İnsani gelişme çok boyutlu bir kavramdır. Birleşmiş Milletler’in İnsani Gelişme Endeksinde kullandığı üç değişken, temel unsurları oluşturmaktadır. Bu üç temel unsur; uzun, sağlıklı ve yaratıcı bir hayat yaşamak; bilgi ve eğitim alabilme imkanına sahip olmak ve insana yaraşır bir hayat için gerekli kaynaklara ulaşabilmektir. İnsani gelişme için öncelikle bu temel unsurlar sağlandığında, hayatın diğer alanlarında ilerleme ve gelişme firsatları da artacaktır.", "İnsani Gelişme Nedir?", ingev (İnsani Gelişme Vakfi), Erişim 12 Nisan, 2018, http://ingev.org/hakkimizda/insani-gelisme-nedir/ "İnsani gelişme için evrensel anlaşma ve insani intibak yardımı gibi insani gelişme raporları içinde yayılmış hoş ve güzel sloganlar dikkatleri iyi bir sonuca çekebilir. Nihayetinde insani gelişmenin sebeplerini artıran politik önerilerin gerçekliği ve analizinin gücü ve sesliliğidir." T. N. Srinivasan, "İnsani Gelişme Yeni Bir Paradigma mı, Yoksa Tekerleğin Yeniden İcadı mı?”, çev. Şenay Sezgin Nartgün, Ankara Üniversitesi Eğitim Bilimleri Fakültesi Dergisi, 1/32 (2007) , s.315. Karamızrak, "Ses ve Müziğin Organları İyileştirici Etkisi”, s.54.

25 Şahin Ak, Avrupa ve Türk İslam Medeniyetinde Müzikle Tedavi Tarihi Gelişim ve Uygulamaları, Konya: Öz Eğitim Yayınevi, 1997, s.5.

26 Pınar Somakc1, “Türklerde Müzikle Tedavi”, Sosyal Bilimler Enstitüsü Dergisi, 15 (2003), s.139.

27 Yönetim fonksiyonları ile ilgili olarak bkz. Ahmet Hamdi Aydın, Yönetim Bilimi Fonksiyonlar, Teoriler, Yaklaşımlar, Ankara: Seçkin Yayıncılık, 2013. 
mada müziği ve müzik aktivitelerini kullanan uzmanlık dalıdır. Nitekim bu sistemlerin yapısında müzik bütün unsur ve araçları ile toplumun hizmetine sunulmak üzere yer almaktadır. Zira müzik kadim toplumların kullandığı tedavi yöntemlerinden biri olarak bilinmektedir. Farklı kültürlerin hastaları tedavi etmek amacıyla başvurduğu en eski toplumsal şifa kültürü usullerindendir. ${ }^{28}$

Toplum tedavisinde doğal yöntemlerin yüzyıllardır uygulandığı bilinmekle birlikte "Müzik, Batı dünyasında ancak 20. yüzyılın ilk yarısında hastane ortamında kullanılmaya başlanmıştır." ${ }^{29}$ Türklerde çok daha önceki dönemlerde, şaman müzisyenlerin ${ }^{30}$ çeşitli hastalıkların tedavisinde müziği kullanmışlardır. Müziğin en bariz iyileştirici kullanımı stresi azaltmaya ve gevşemeye yöneliktir.

Tedavi edici etkisi ile "Yapılan çalışmalarda müzik terapinin aynı zamanda terapist ile hastanın sözel iletişime geçmesine olanak sağlayan bir tedavi yöntemi olmasının hastanın psikolojik semptomlarına büyük ölçüde etki ettiği vurgulanmıştır.” ${ }^{31}$ Müzik iyileşme sürecinde güçlü bir hızlandırıcı görevi görebilir.

“The Economist Intelligence Unit” tarafından hazırlanan ve 2013 yılını kapsayan yaşam kalitesi endeksinde ${ }^{32}$ ülkelerdeki bireylerin yaşamlarını etkileyebilecek çeşitli faktörler arasında "kişisel psikolojik mutluluk" unsuru da yer almıştır.

Psikolojik/emosyonel durumun kapsadığı; yaşamdan doyum bulma, yararlılık, beden imajı, anksiyete, otonomi, dinlenme ve meşguliyet ile ilgili durumlar, bir iş tamamlama, yaşamın anlamı, yaşamın normalliği ve mutluluk gibi duygulardır. Bu sakinlik, zindelik ve sağlıklı halin gerçekleşmesine etki eden unsurlardan biri de yaşam kalitesi (quality of life), kişinin içinde yaşadığ sosyokültürel ortamda kendi sağlığını öznel olarak algılayışını tanımlamaktadır. ${ }^{33}$

Böylece bir müzikal uygulamanın elemanları arasında (söz, nota, enstrümanlar, icrac1lar, dinleyiciler, mekan ve akustik yer almakta) işbirliği ve koordinasyonu kurarak, "beğeni" ve "kalite" sağlayacak biçimde ve stratejik plan kapsamında bütün bileșen-

28 Orta Asya döneminde Türklerin şaman uygulamalarında görülen müzik aletlerinden kopuz veya saz tedavi edici, iyi ruhları çağıran, kötü ruhları kovan önemli bir çalgı olarak kullanılmıştır. Şamanlar tarafından Altaylar ve kuzey bölgelerinde hasta tedavisinde ve dini törenlerde davulların da kullanıldığı kullanılmıștır. Bkz. Somakcı, “Türklerde Müzikle Tedavi”, s.133. Karamızrak, "Ses ve Müziğin Organları İyileştirici Etkisi”, s.55. Jonathan Goldman, Seslerin Gizli Gücü, İstanbul: Sınır Ötesi Yayınları, 2010, s.18, 20, 36-9,161-180. Campell, Mozart Etkisi, s.156-7,160-2, 272-343.

29 Karamızrak, "Ses ve Müziğin Organları İyileştirici Etkisi”, s.55.

30 Orta Asya’da bu müzisyenlere "Baksı" (görücü, gören, bakan) ya da bahşı verilmekteydi. Kam, şifacı veya tedavici diyebileceğimiz kişiler müzik ve dansı, toplum içindeki dengeleri sağlamak, ihtiyaçlara cevap vermek, hastalara şifa vermek ve diğer rolleri ile sosyo-kültürel ve spritüel bir fenomendir. Türk kültürü ve günlük yaşayışında çok eski zamanlardan beri yer almakta olan Baksı veya Kam adı verilen tedaviciler, icra ettiği müzik, ritim ve danslarla bir sanatçı gibi görünmekle birlikte kopuz, topşuur, komuz ve kıyak gibi müzik âletleri ve çeşitli ritim sazlarıyla trans haline geçip o trans içinde sezgi bilgisinden bahsettiği için aynı zamanda bir medyumdur. Bkz. Abdülkadir İnan, Tarihte ve Bugün Şamanizm, Ankara: Türk Tarih Kurumu Basımevi, 1986, s.31.

31 Bensu Kitirci, "Palyatif Bakım Ünitelerinde Uygulanan Müzik Terapi Çalışmaları Üzerine Bir Araştırma”, Afyon Kocatepe Üniversitesi Akademik Müzik Araştırmaları Dergisi (AMADER), 4/8 (2018), s.82.

32 "Where The Living is Easier -Daily Chart- The Economist", Mar 12th 2012 by The Economist online, Erişim 2 Mart, 2018, http://www.economist.com/blogs/graphicdetail/2012/03/daily-chart-8?zid=292\&ah= 165a5788fdb0726c01b1374d8e1ea285.

33 Ayrıntılı bilgi için bkz. Faruk Sapancalı, Toplumsal Açıdan Yaşam Kalitesi, İzmir: Altın Nokta Yayınları, 2010. 
lerin bir araya getirilmesi gerekmektedir. Bu makro planın stratejik değerlerinden biri “işbirliğini” örgütleyebilme yeteneğidir. Nitekim bu işbirliğinin olumlu sonuçlar üretebilmesi için teknik olanaklar, mekan koşulları ve sosyo-kültürel doku ile uyum gibi koşullar ${ }^{34}$ da dikkate alınmalıdır.

Sanayileşmenin yarattığı etkinin bilişim toplumuna açılımı ile “Ticaret dünyasında, insanlar müzik endüstrisi kelimelerini kayıt endüstrisi olarak anmaya başlamış, 2000'li yıllarla birlikte dünya müzik pazarı üç büyük şirket ve marka tarafından kontrol altına alınmıştır. Bunlar; Fransız kuruluşu olan Universal Music Group, Japon kuruluşu Sony Music Entertainment, A.B.D. kuruluşu Warner Music Group’tur. Diğer kuruluşlar ve markalar ise genellikle bu kuruluşlara bağımlı çalışmışlardır.” ${ }^{35}$

20. yüzyıl başlarında müziğin tanımlayıcı özelliğinin titreşimlerdeki düzenlilik olduğu genel kabul gören bir görüştü. Teknolojik ilerleme sonucunda elektronik aygitlar vasitasıyla besteci ve yorumcunun geleneksel rolünü ortadan kaldırarak eserin dijital ortamda üretilerek kaydedilmesine olanaklar sağlamıştır.

Toplumda sanatın değişik dalları birbiri ile uyumlu biçimde kültürel yaşamın oluşumuna ve sürdürülmesine katkı sağlamaktadırlar. Bu çerçevede müziğin tarihi serüveninde müziğin üretiminden tüketimine kadar gerçekleşen süreç toplumsal yapının içeriği ile senkronik (eşzamanlı) bir özellik gösterir. Her müzik eseri, tarihin koridorlarından bizlere felsefi temelleri olan, estetik yargılar ve içinde şekillendiği toplumsal kültür kimliği ile seslenir.

Günümüzde dijital platformlarda gerçekleşmekte olan müzik üretiminin değişim trendinde “....1880’lerin sonunda ticari olarak yayımlanan müzikal performansların fonograf kayıtları, 1920'lerde yayın hayatına başlayan ve oldukça geniş kitlelere ulaşabilen radyo yayınları ile müziğin işitilmesini kökten değiştirmiştir." ${ }^{36}$

\section{Müzikte ve Siyasette Uzlaşı ve Ahengin Tarihsel Kodu: Adil Paylaşım}

Söz, ritm ve ezginin iletilmesi önemli bir işlev olması yanında iletinin (söz ve ezginin) dinleyicide "anlamlandırılması" olgusu bugün özellikle "barış" ve "kardeşliğin" bütün toplumların ortak özlemi haline geldiği bir dünyada müzik ve müzik üretileri ile yaratıcı müzik atölye uygulamalarının anlam ve işlevini ön plana çıkarmıştır. Bu kapsamda olmak üzere müzik olgusunu eser, ürün anlamında ifade eden "söz ve melodiler” ve bunları oluşturan bileşenlerin uyum ve organizasyonu, müziği oluşturan bütün maddi ve anlamsal değerlerin işbirliği kritik bir öneme sahiptir.

Bilgi toplumunda ilerlemenin temel koşulu, yaratıcı ve yenilikçi (inovatif) düşünme ve değişim mühendisliği (reengineering) uygulamalarına açık ulusal entelektüel sermayenin özelliği, yeni ürünlerin ve yeni düşüncelerin oluşması, bireylerin yaratıcı güçlerini ortaya çıkarmaları ile doğru orantılıdır. Bireylerin yaratıcılık potansiyellerini ortaya çıkarıp, geliştirmelerinde uygun bir öğretim ortamı oluşturmak ve uy-

34 Müziğin sosyoloji ve kültür ile ilişkisi konusunda bkz. Bkz. İlhan Tekeli, Gündelik Yaşam, Yaşam Kalitesi ve Yerellik Yazıları, İstanbul: Tarih Vakfı Yurt Yayınları, 2010.

35 Arapgırlığlu, “Dünyada ve Türkiye’de Müzik Endüstrisinin Dünü, Bugünü ve Yarını”, s.3.

36 Arapgırlığlu, “Dünyada ve Türkiye'de Müzik Endüstrisinin Dünü, Bugünü ve Yarını”, s.4. 
gun öğretim yöntemlerini etkin bir şekilde kullanmak esastır. Bu sürecin farklılaşma paradigması, matematik, dil, estetik, müzik ve siyaset eksenlerini toplumsal ölçekte anlamlandırarak birbirleri ile ilişkilendirebilmesidir. Kesin olan her şeyin bir sonraki kesinliğe kadar olan doğruluğu müzik ve estetik de sonsuza erişebilmektedir. İnsanın duygu ve düşüncelerine mantık ve matematiksel doğruların ötesinde ulaşarak yaşayan bir arşiv oluşturan ortak dil, duygu, estetik ve değerler arşividir.

Kültür evreninde bütün farklılıkların etno-folklorik özellikleri ile doğasında taşıdığ "güzele dair zenginlikleri" ile büyüleyici etkiler üretmektedir. Müzik aynı zamanda anlamın ve duygunun iletilme işlevi ile "Müzik melodisi, sözcüklerin anlaşılmasında taşıyıcı bir araç olarak görev yapar. Duygu, yaşamımızın merkezindedir ve iletişim, isimlerin ve sözcüklerin çok ötesinde hislerimize, davranışlarımıza ve kişilere anlam katar." ${ }^{37}$ Diğer canlılardan farklı olarak "İnsan alg1sı, özleri insan sesi olan konuşma ezgisi ile müzikal ezgi arasında ayrım yapmakta ve bunları ayrı ayrı işlemlemektedir. Şüphesiz, konuşucu için dilin en temel niteliği anlam taşıması ve bu sayede iletişimi gerçekleştirebilmesidir." ${ }^{38}$

Tarihsel olarak insan-doğa ilişkilerinin toplumsal değişimlere zemin hazırladığı müzik alanındaki gelişmenin de doğadan sesleri taklit ederek öykünerek öğrendiği ve insanların her dönemde müzik ve doğa ile iç içe olduğu anlaşılmıştır.

Bu konuya ilişkin olarak örneğin; “Picasso’nun Müzisyenler’inde, Ortaçağ İtalyan Tiyatrosu Commedia dell’ Arte ${ }^{39}$ nin, sahnede hep yer alan üç baş kişisi gösterilir: Elinde çalınacak notayı tutarak Devlet'i temsil eden Papaz ile Halk'ı temsil etmek üzere elinde kavalıyla duran çobanın arasında, gitarını çalmakta olan "sanatç”" oturur." ${ }^{40}$ Bu tablo bir uyumu ve işbirliğini gösteren bir yapı ortaya koymaktadır.

Yaklaşı 2500 yıl önce Platon'un ortaya koyduğu müziğin Antik Yunan'da toplumsal bir etkinlik olduğuna dair anlayış ${ }^{41}$ günümüzde de geçerliliğini korumaktadır. $\mathrm{Bu}$ gün olduğu gibi o dönemde dahi kutlamaların müzik ve şiir ile birlikte gerçekleştirildiği, toplum içerisindeki rolü ortaya konulmaktadır.

Platon’a göre, taşıdığı etik değer sayesinde müzik insan ve toplumun eğitimindeki faydasına dikkat çekmiştir. Ona göre armoni (harmonia) yani uyum, aynı zamanda insan ruhu ve evrenin uyumunu kapsar.

Platon’un müziğin insan karakterini biçimlendirebilme gücü taşıdığı kanısına karşın

37 C. Hakan Çuhadar, “Müziksel Zeka”, (Ulusal Müzik Eğitimi Sempozyumu’nda Sunulan Bildiri, Pamukkale Üniversitesi Eğitim Fakültesi, Denizli, 26-28 Nisan 2006), s.494. Ayrıca bkz. Howard Gardner, Zihin Çerçeveleri, Çoklu Zeka Kuramı, çev. Ebru Kılıç 3.Baskı, İstanbul: Alfa Yayınları, 2017. Isabelle Peretz and Robert J. Zatorre, "Brain Organization for Music Processing", Annual Review of Psychology, 56/1 (2005).

38 Özay Önal, “Ses, Dil ve Müzik”, s.10.

39 Commedia dell Arte (-), “Tiyatro Dünyası”, Erişim 27 Nisan, 2018, http://www.tiyatrodunyasi.com/2007/04/ commedia-dell-arte-56283.

Ebru Balamir, “Commedia Dell'arte, Tiplemeler ve Carlo Goldonı ile İtalya'da Tiyatro Reformu”, Rumeli de Dil ve Edebiyat Araştırmaları Dergisi, 2017.

40 “Çoksesli Müzik ve Topluma Etkileri”, Erişim 27 Nisan, 2018,

http://www.sanatteorisi.com/sanatteorisi.asp?sayfa=Makaleler\&icerik=Goster\&id=2719.

$41 \mathrm{Bu}$ konuda ayrıntılı bilgi için bkz. Nesrin Akan, Platon'da Müzik, İstanbul: Bağlam Yayıncılık, İkinci Basım 2017. 
Aristoteles, mutluluk ve hazzı hem bireyin, hem de devletin değerleri olarak kabul etmişti. Yalnızca müzik konusunda kuramsal bilgi sahibi olanlar ile müziği üretenler arasında ayrım yapıyor, müzik yapmayan insanların başkalarının yaptığı müziği yargılayamayacaklarını savunuyordu. ${ }^{42}$ Söz ile "hem Sokrates hem Platon için söz, müziğin mutlak bileşenidir. Onlara göre müzik sözsüz olamaz ve olmamalıdır.” ${ }^{43}$

Günümüzde özellikle çoksesli müzik yaklaşımı ile orkestra olgusu ve yönetimi bu işbirliği ve koordinasyon zorunluluğunun bir göstergesidir. Müzikte işbirliği, üretinin niteliği ve kalitesi ile ilgili olurken, koordinasyonu da niceliğinin ortaya çıkardığı bir gereksinim olmaktadır.

Müzikte toplumu etkileyen ve toplumdan etkilenen gelişmelerin ve çoksesliliğin ortaya çıkması Avrupa da ki Rönesans ve Aydınlanma hareketlerinin sonucu olmuştur. Bilindiği üzere "Aydınlanma Çağı, batı uygarlığının yeni insan ve toplum inşa etme projesinin düşünsel ve felsefi temellerinin oluştuğu çağdır." 44 Teknolojik ilerlemenin müzik alanında uygulanması ile hem enstrümanların kullanılması olanaklarını arttırmış hem de yeni gelişmelere ve işbirliği yöntemlerinin ortaya çıkmasına pozitif katkı sağlamıştır. Yeni yorum biçimleri, beste tarzlarında ilerlemeler ve nota okuma-yazma teknikleri ile iletişim araçlarında sağlanan hızlı gelişmelerle birlikte kültürlerarası iletişim ve etkileşim artarak küresel ölçekte yoğunluk kazanmıştır.

Müzik eserinin, yaratıcısının kimliğini ortaya koymasında temel öge esere kazandırdığı özgünlüktür. Johann Sebastian Bach (1685-1750), Ludvigvan Beethoven (17701827), Wolfang Amedeus Mozart (1756-1791), Franz Schubert (1797-1828), Johannes Brahms (1833-1897), Richard Wagner (1813-1883) gibi ünlü müzik bestecileri dünyanın her coğrafyasında farklı toplumların müzik kültürü içinde yer alarak, müzik endüstrisinin de önemli değerleri arasında varlıklarını sürdürmektedirler.

Örneğin, Johann Sebastian Bach’ın ses aralıklarını eşitleyerek dengelemesi (tampere gam), bugünkü piyano ile birlikte, ezgiye, değişik seslerle, uyumlu bir biçimde eşlik etme olanağını yarattığı gibi, iki ezginin üst üste bindirilmesinden elde edilen uyum (armoni) üzerinde araştırmalara da olanak sağlamıştır. ${ }^{45}$ Bütün bu gelişmenin dinamiğinde özgün olma kaygısı ile duygu ve düşüncenin sihirli işbirliği yer almaktadır.

İnsan ve toplum kalitesi rasyonel ve adil bir yönetimin gerçekleştirilebilmesinin koşullarından biridir. Ancak olmaz ise olmazı değildir. Çünkü "adalet” hukuk devletinin, "adil” olmak da ahlaklı yöneticilerin göstergeleridir.

\section{Müzikte ve Siyasette Ortak Mantık Kurmanın Yolu: Aklın ve Duygunun İşbirliği}

Toplumdaki siyasal otorite ile ilgili kurumların ve bu kurumların oluşmasında ve

42 Bu konuda detaylı bilgi için bkz. “Müzik”, Erişim 27 Nisan, 2018, https://www.turkcebilgi.com/m\%C3\%BCzik. 43 Ayna İsababayeva Apaydın ve Fazlı Arslan, "Antik Yunan Felsefesinde Ahlaki Eğitim Aracı Olarak "Müzik”, Değerler Eğitimi Dergisi, 29-Ek-Özel /13 (2015), s.326.

44 A. Kadir Çüçen, “Batı Aydınlanmasının Düşünsel Kökenleri ve Eleştirisi”, Muğla Üniversitesi Sosyal Bilimler Enstitüsü Dergisi (İLKE) Atatürk'ün Doğumunun 125. Yılı ve Cumhuriyetimizin 83. Yılı Özel Sayısı, 2006, s.26. 45Geniş bilgi için bkz. Deniz Kaya, Johann Sebastian Bach’ın “Füg Formları”nın ve "Füg Sanatı" Adlı Eserinin Barok Dönem Müzik Anlayışına Göre İncelenmesi, Yüksek Lisans Tezi, Çukurova Üniversitesi, 2009. 
işlemesinde rol oynayan etkenler ve bu yapının derinleşen sebep-sonuç ve aralarında ilişkilerin incelenmesi siyasal bilimcinin başlıca işlevidir.

Siyaset bilimi araştırmacısı, bugün olması gerekenle uğraşmayı bırakıp, "gerçekte olanı” kendine konu almış ve teknik analiz yapmanın uğraşı içine girmiş olmalıdır. Toplumda gözlediği gerçekleri toplar, sınıflandırır ve bir analize sokar. Siyasal kültürün bir parçası olan değer yargılarını bir olguymuş gibi inceler fakat değerlendirmesine girmez çünkü normatif yorumların yerini pozitif araçlar ve somut bulgu ve verilere dayalı değerlendirmeler almıştır. Bu süreçte saha çalışmaları gözlem yöntemini kütüphane çalışmaları ve istatistik verilerin incelenmesi siyasal bilim araştırmacısının vazgeçilmez yöntem ve araçlarıdır.

21. yüzyılda yaşam anlayışında değişmelerle farklı coğrafyalarda yaşayan toplumların sanat ürünleri birbirinden farklı özellikler taşımakta olduğu görülmektedir. Bununla birlikte müzik akımlarında var olan toplumsal ve kültürel etkileşim ve müzik anlayışları üzerinden kurulan "ortak akıl” insani ve kültürel değerlerin bütün toplumların/insanlığın 'ortak kültür değerleri' olarak kabul edilmesinde önemli rol oynamıştır ve oynamaktadır. Bu farklı dinamiklerden biri olan müzik aracılığıyla hem toplumların sosyo-kültürel yapısını hem de diğer toplumlarla olan etkileşimleri kavranabilir. Not edelim ki “yeni küreselleşme dalgası, bir taraftan siyasal yapılar üzerinden ulusal düzeyde idari, toplumsal ve kültürel her türlü sınırlamaları ve geleneksel yönetim yaklaşımlarını geçersiz kılarken, diğer yandan kitle iletişim yapılarını dönüştürerek 'siyasal ileti' formunu yeniden biçimlendirmekte ve toplumları kültürel dönüştürmeye olanak sağlayacak aracı yapıları oluşturmaktadır." ${ }^{46}$

Müzik anlayışları ve müzik ürünlerinin, temsil ettiği kültür değerleri sanatın yaşama kattığı değerlerle toplumların gelişmişliklerini ve değişimlerini belirleyici bir işlev kazanmıştır.

$\mathrm{Bu}$ etkileşimleri kimi zaman kullanılan melodik yapıdan, ses aralıklarından, çalgılardan, kimi zaman da melodi-söz uyumu ve söz içeriklerinden anlaşılabilmektedir. Bu yolla toplumun aile yapısı, eğitim anlayışı, siyasi görüşleri, teknoloji kullanımı, ekonomik durumları, psikolojileri, dini inanışları, üretim ve tüketim yaygınlığı, gelenekleri ve toplumun değer yapılarına ilişkin bilimsel verileri elde edilebilmektedir.

Bireylerin yetişme sürecinde müziğin ve müzik eğitiminin rolü önemli olup müzikle ilgili davranışlar geliştirmek ve kazandırmak ancak planlanmış ve programlanmış bir eğitim süreci ile mümkün olacaktır. Tarihsel olarak sonra ki dönemlere de 1şık tutacak şekilde bu hususa Platon ${ }^{47}$, Aristoteles ve Pythagors gibi filozofların dikkat

46 İrfan Paçacı, Küreselleşme Sürecinde Yönetim ve Medyanın Dönüşümü, İstanbul: Akademi Titiz Yayınları, 2013, s. 120 .

47 Örneğin Platon "gençler bir sağlık ülkesinde yaşıyormuş gibi her şeyden yarar görsünler, güzel yapıtlardan gözlerine veya kulaklarına değen her şey, dünyanın en güzel ülkesinden sağlık getiren bir rüzgar gibi, onları diriltsin, ta çocukluktan güzeli sevmeye, güzele benzemeye, güzelle uyum içinde yaşamaya doğru onları usulca götürsün. Bu nedenlerden dolayı müzikle eğitim en üstün eğitimdir, çünkü ritm ve uyum, ruhun ta içine girer ve onu uyumlu kılar" diyerek eğitimin müziğe dayanmasını savunur. Aristoteles ve Pythagors ise, müziğin insan ruhunun eğitiminde ve temizlenmesinde önemli bir araç olduğunu vurgulamışlardır. Bkz. Platon, Devlet, çev. 
çekmiş oldukları görülmektedir.

Müziksel davranış kazandırmada eğitimin kuramsal, ses ve çalgı ile ilgili olmak üzere üç temel boyutuna ilişkin olarak; gerekli olan yeterliklerin kazandırılmasında materyallerin hazırlanarak sürece aktarılması ile ilgili konuda; planlama, yöntem, strateji, iletişim ve değerlendirme aşamalarının güçlü bir “işbirliği” gerektirdiği açıtır.

Müzik aracılığıyla sosyal etkileşimin yaratıldığı alanlar ve bunun uzantısı olan kültür ve kültürlerarası etkileşime müziğin katkısı çağdaş toplumların başlıca göstergeleri arasında yer almaktadir.

Müzik toplumsal yaşamı sosyal moraliteyi düzenleyerek sağlıklı kılan bir işlevi yanında müzik eğitimi ile de katkı sağlamaktadır. Nitekim “Müziği bütüncül bir yaklaşımla, temel sosyal kurumlardan sanat içinde ele alıp incelemek onun toplumsal yönüne dikkat çekmektir. Müzik çoğu kez bir manevi kültür unsuru olarak görülmekle beraber kültürün maddî yönüyle ve sosyal yapıyla da ilişkisi vardır. Müzik üretiminde fikrî, sosyal ve teknolojik unsurlar bir arada bulunurlar.” ${ }^{48}$ Günümüzde yaygın ve geniş bir etki sahasına sahip olan popüler kültür ve onun bir aracı olarak popüler müziklerin çekici cazibesine karşı etkili çözüm yollarından biri, o şarkı sözlerinin, görsel tasarım ve motiflerin olumsuz etkilerini azaltabilecek şekilde milli ve, çocukların gelişim özelliklerine uygun nitelikte müzik yapıtları üretmek olacaktır. $^{49}$

Bu konuda büyük düşünür Aristoteles’in dile getirmiş olduğu düşünce müziğin toplum bakımından çok yönlü işlev ve faydalarına işaret etmektedir.

"Müziğin ahlâk dengesi ve onun bir eğitim aracı olarak kullanılması gereği her çağda kabul edilmiştir. Bundan ötürü müziğin ahlâk gücünü inkâr etmek elde değildir. Ve madem ki bu güç onda vardır; çocukların eğitiminde de müzikten yararlanmak gereklidir." ${ }^{50}$

Müzik insanın sosyal hayatın birçok alanında farklı işlevleri ile iletişim aracı özelliği olan ve özünde sosyal bir olgudur. Müzik milli kimliğin oluşturulmasında yer alan bir kimlik göstergesi olup; toplumsal kimlik bilincinin belirlenmesinde ve fertlerin ortak estetik, kültürel ve moral değerler etrafında birleştirerek toplumla bütünleşmelerinin sağlanmasında rol oynar.

Toplumda müzik kültürünü etkileyen sosyo-ekonomik, kültürel ve çevresel faktörlerin belirlenmesi amacıyla yapılan çeşitli araştırmalarda ortaya konulmuş ayrıca: "Müziğin insanları siyasal açıdan biçimlendirmede çok önemli bir etkiye sahip olduğu çeşitli tarihsel olaylarda görülmüştür.”

Cem Taşkıran, Ankara: Pan Kitapevi Yayınları, 2005, s.117.

48 Fatma Odabaşı, “Dil-Kültür Bağlamında Müzik Dili ve Bunun Sosyal Bütünleşmedeki Yeri”, İstanbul Üniversitesi Illahiyat Fakültesi Dergisi, 14 (2006), s.248.

49 Alp Özeren, "Çocuklar İçin Yaratılan Müzik Yapıtlarının Toplumsal Müzik Bilinci ve Dil Gelişimi Açısından Rolü ve Önemi”, (II. Ulusal Çocuk ve Gençlik Edebiyatı Sempozyumunda Sunulan Bildiri, Ankara Üniversitesi Eğitim Bilimleri Fakültesi, Ekim 04-06, 2006.)

50 Erdem Gedikli, Müzik Eğitimi, Bursa: Ezgi Kitabevi, 2003, s.131.

51Fahri Kılıç, "Çok Sesli Batı Müziğinin Türk Modernleşmesindeki Önemi”, 38. ICANAS (International Congress 
Toplumsal yaşamda sanatın ve müzik eğitiminin önemli bir yeri ve değeri bulunmaktadır. Özünde toplumsal nitelikte farklı işlevlere taşıyan müzik, sosyal hayatın bir çok alanında insanın iyi bir iletişim aracı olarak yer almaktadır. ${ }^{52}$ Hayata renk, değer ve anlam katan müzik esasında bir çok yönden sosyal yapı ve toplumsal yaşam ile ilgilidir. Nitekim, “Müziği bütüncül bir yaklaşımla, temel sosyal kurumlardan sanat içinde ele alıp incelemek onun toplumsal yönüne dikkat çekmektir. Müzik çoğu kez bir manevi kültür unsuru olarak görülmekle beraber kültürün maddî yönüyle ve sosyal yapıyla da ilişkisi vardır. Müzik üretiminde fikrî, sosyal ve teknolojik unsurlar bir arada bulunurlar." ${ }^{53}$

Teknolojide baş döndürücü ilerleme ve kitle iletişim araçlarındaki gelişme müzik alanında da büyük atılımlara yol açmıştır. Özellikle yeni kitle iletişim (radyo, televizyon gibi) araçlarının geliştirilmesi müziğin yaygınlaşması, müzik alanına elektroniğin girmesi ile değişik ses ve uygulamalara olanak sağlamış ayrıca farklı toplumların müzik türlerinin de dolaşımının ve tanıtımının sağlanması ile müziğin evrenselleşmesi gerçekleşebilmiştir.

Bütün bu gelişmeler neticesinde müzik:

“Temel fonksiyonu toplumun kültürünü oluşturmak, iletişimi sağlamak ve kültürel mirasın aktarıcılığını yapmak, toplumun kimliğini belirlemek olan dil, aynı görevi yapan ve toplumun inanç sistemini oluşturan din gibi müzik de bu fonksiyonları ifa etmektedir. Müzik de, diğer ikisi gibi toplumun kimliğini belirlemek, bu kimliğin bilincine varılarak fertlerin toplumla bütünleşmelerini sağ lamada önemli rol oynar. Duygusal iletişim özelliği yanında, toplum üyelerini benzeri estetik değerler etrafında birleştirerek kültürel ve sosyal bütünleşmede önemi haizdir. Müzik de dil ve din gibi kimlik göstergesidir." 54

\section{Sonuç}

"Doğu" ile "Batı" toplumları arasındaki temel farklılıklardan biri de "siyaset" ve özellikle "siyasal iktidar" anlayışı üzerine olup bu farklı yaklaşım kendini açık biçimde de "siyasal iktidar ilişkileri” bağlamında sergilemektedir. Batı toplum düzeninde siyasal iktidar ilişkileri monarkın mutlak tekelinin dağıtılması ile parçalı ve dağıtılmış bir iktidar sistemini esas alan "kuvvetler ayrımı"; doğu toplum yapısının şekillendirdiği siyaset biçiminde ise siyasal iktidar parçalı değil "toplayıcı" ve rekabete açık sosyal güçler dengesine dayalı değil devlet iktidarını güçlendiren ve düzeni her vasıtayla güçlendiren bir yaklaşım içinde "hak ve özgürlükleri", "sivil toplum ve sosyal güçleri” tanımlayan bir merkeziyetçi bir yapının toplayıcı kodu olagelmiştir.

Sözü edilen yapı Türk sisteminde 150 yılı aşkın bir süreç içinde gelişerek kendi modelini; "demokrasi” fanus da "toplum” da vesayet altında bir "iktidar" kurumsallaş-

of Asian and North African Studies - Uluslararası Asya ve Kuzey Afrika Çalışmaları Kongresi, , Ankara, Eylül 1015, 2007), Atatürk Kültür Dil ve Tarih Yüksek Kurumu Yayınları: 9, I. Cilt, 2009, s.456.

52 Bkz. Odabaşı, “Dil-Kültür Bağlamında Müzik Dili ve Bunun Sosyal Bütünleşmedeki Yeri”, s.249, 250.

53 Odabaşı, "Dil-Kültür Bağlamında Müzik Dili ve Bunun Sosyal Bütünleşmedeki Yeri”, s.248.

54 Odabaşı, "Dil-Kültür Bağlamında Müzik Dili ve Bunun Sosyal Bütünleşmedeki Yeri”, s.254, 255. 
masının unsurları olarak anayasal siyasal hukuk düzeninin alt sistemleri olarak yer almak üzere oluşturmuştur.

"Doğu” ile "Batı" toplumsal-siyasal düzenleri arasında ki "demokrasi” farklılaşması "ve "siyaset" anlayışlarındaki farklı okumaların özünde "doku uyuşmazlığı" bulunmaktadır. Batı toplumlarının siyasal gelişmesinin ürünü olarak ortaya çıkan (Batı) demokrasi(si) orada yaşam biçimi haline gelirken doğu toplumlarında ise ayrışmanın, ötekileştirmenin ve çatışmanın adeta "aracı" olmaktadır. O sebeple mutlak iktidar, çoğunlukçu yönetim, iktidarın temerküzü, kanuni yönetim "denetim dişı rutin alanlar/işlemler”, "anayasal denetim”, “yargı denetimi” gibi yapılardan uzaklaşarak kanun devletine dönüşerek hukuk devleti kodu "polis devleti” görüntüsü altında ikiz yapılı devlet sistemi ve rejim biçimi ortaya koyarak "demokrasi" de dayanağı olan "anayasa" da giderek "millileşme" etkisinden kurtulamamakta dolayısıyla "evrenselleşme" bağlarını oluşturamamaktadır.

"Muhalefet” bu yapı da meşru görülememekte, haklar ve özgürlükler kurumsallaşamamakta, "sivil toplum" mekanizmaları siyasetin araçları arasında yerini alamamakta, akademi görmemezlikten gelinmekte ve evrensel hukuk olgusu ile bu "yapı-işleyiş" karşı karşıya geldiğinde "yok" sayılmaktadır.

Çağdaş toplumlarda müziğin değer ve anlamı, özgürlüğün, demokrasinin, barışın, sevginin ve yaşamın çoksesliliğinin evrensel anlatımı olarak anlaşılmaktadır. Bir bütünün parçaları arasında bulunan uygunluk ve ahenk, üretilen eser ile oluşan “değerin" nihai aşamadaki katkısının olumlu veya olumsuz olarak nitelendirilmesinde de belirleyici bir işleve sahiptir.

Müzik, insanoğlunun, doğadan esinlenerek, düşüncelerini özgürce dile getirip ürettiği ve kültürlerarası etkileşim ve iletişimin sağladığı olanaklarla toplumsal hayatın bütün boyutlarında etkili sonuçlar üreten bir güce ulaşmıştır.

Böylece müziğin toplumları etkileme gücü ile bir “barış ve kardeşlik köprüsü” olma misyonu elde ettiği görülmektedir. Müzik bu katkısı yanında, çağdaş toplum olmanın ölçütlerinden ve bilimsel gelişme ve kalkınmanın araçlarından biri olma gibi özellikler kazanmıştır.

İş bölümü, grup halinde yapılacak işlerin grup üyesi bireyler tarafından paylaşılmasıdır. Diğer toplumsal etkinlikler gibi müzik ile gerçekleştirilen uygulamalar da bireysel olmaktan çok topluluklara yönelik kitlesel bir işlev olarak icra edilmektedir.

Müzik kuram ve uygulamalarının gelişiminde; beğeni ve sürdürülebilir farklılıklar, özgünlük arayışları ve etkileşim, vizyon kazandırıcı başlıca özelliklerdir.

Müzik anlayışlarını yeniden biçimlendiren bu nitelikler, aynı zamanda yeni yetenek ve yaklaşımların değişik ölçekte ve sayıda kişi tarafından icra edilmesine olanak vermektedir. Nitekim bu eksende ortaya çıkan yeni yaklaşım biçimlerinden biri olarak; orkestra ile çalışan bir müzik tarzı/modeli, müzikte kurumsallaşmanın bir yansıması olurken aynı zamanda çok sesliliğin de giderek yerleşik hale geldiği görülmektedir. 
İletişim alanında yaşanılan hızlı gelişmeler ile kitle iletişim araçlarındaki baş döndürücü değişim; müzik alanında da küresel ölçekte hızlı bir atılımın gerçekleşmesine olanak sağlamıştır. Yeni iletişim araçları ve teknolojileri ile müziğin olağanüstü ölçüde yaygınlaştığ 1 ayrıca belli başlı müzik türlerinin de evrenselleștiği görülmektedir. Elektroniğin müzik alanına uygulanması ile müziğin dinleme, üretme ve yorumlama boyutlarında yeni değişimlerin ortaya çıkmasına yol açmıştır.

Müzik gibi toplumsal hayatın ve faaliyetlerin merkezinde gerçekleşen siyaset de çoğulcu, çok sesli ve farklılıkların oluşturduğu bir ortamda şekillenmektedir.

Siyaset, insan hayatındaki maddi ve manevi değerler ekseninde ki bütün ürünlerinin paylaşımına yönelik süreçleri kapsayan anlamı ve işlevi ancak yönetilenler için "adil", “özgür" ve "erdemli” bir "yönetim" modeli üretebildiği ölçüde değer kazanacaktır.

Bütün bu gelişmeler, toplumla ilgili diğer faaliyetlerde olduğu gibi müzik ve siyasetin de bir "işbirliği" ve "işbölümünün" koordineli, uyumlu bir bütünün birleştirilmiş parçalarının toplamı olduğu ve ancak bu bileşenler etrafında insanı mutlu edebilecek sonuçlar üretebildiği gerçeğini ortaya koymaktadır.

Not edelim ki, insanlık ortak kültür mozağinin "paylaşımcı ve etkileşimsel işbirliği”ni temsil eden alanlardan biri olan müzik, siyaset ile; barış ve özgürlük ortak hedeflerin, işbirliğinin, uyum ve uzlaşının, ahengin ve adil paylaşımın esas olduğu aklın ve duygunun işbirliği ile bir "ikiz alan" oluşturmaktadır. Bu değer ve normları kurmanın yolu olarak müzik ve siyaset, taşıdıkları özellikler ile adeta bir "ikiz alan hipotezi" kurulmasına esin kaynağı olmuştur.

21. yüzyılın ilk çeyreği içinde yeniden kurulmakta olan küresel yönetim ve onun stratejik "yeni dünya düzeni” mühendisliği ile yeniden yapılandırılmakta olan gelişme yolundaki toplumlar ve onların siyasal-yönetsel düzenleri ile ilgili süreç kültür, sanat ve müzik alanlarını da kuşatarak biçimlendirmektedir.

Küreselleşme politikaları ile ekonomik düzenler ve siyasal rejimler üzerinde kapitalizmin revizyonu ile ilgili değişim kültür ve sanat alanında yeniden inşa çalışmaları; duygu, düşünce ve anlamın yeniden üretim ve yorumu olarak ortaya çımaktadır.

$\mathrm{Bu}$ değiş(tir)menin dinamiğinde; üretim yapısı ile refah ve paylaşımın dengesini, siyasal iletişim düzeni ile kamuoyu algısını, popüler kültür üretileri ile de yeni kuşakları egemenliği altına alarak "yeni bir küresel toplum" inşa hedefi yer almaktadır.

Küresel kapitalin bu yapısal tasarımın pratikte gerçekleşmesiyle birlikte; özgürlük, toplum ve kültür arasındaki bağ kesilerek, özgün ve milli kültür akımının işleyişi değiştirilmekte ve böylece "halk", "aynılaştırıp, tüketim odaklıllğa" doğru yönlendirilerek yönetilmektedir.

Ekonomik krizin nedenlerini, siyasal planda ürettiği "gerçek" (!) ile suni biçimde kurguladığı alternatifsizleştirme söylemi ekseninde toplayarak, oluşturduğu toplumsal yapıda, temel olan yabancılaşmayı ve bu yabancılaşma içinde "iki eksenli - biz ve onlar" olarak ürettiği siyasetin tek tipleştirici etkisiyle, ortalama insanın kolayca al- 
gılayamayacağı bir düzeyde bu yapay gerçekliği ve ona bağlı siyasallaşma içeriklerini benimseterek kendi eskinin reddiyesi üzerine "yeniyi” kurar.

21. yüzyılın sentetik ve dijital kültür sanayicileri; sinemada, televizyonda ve sosyal medyanın değişik mecralarında üretip yayına koydukları ürünler ile yapay bir eğlendiricilik sergileyerek, cezbedici ve büyüleyici kılarak yerel ve milli köklerinden kopararak, metalaşmasını doğallaştırdıkları materyalist bir kültür-sanat ve müzik düzeni kurmaktadır.

Böylece, küreselleşme süreci ile birlikte kültür gibi müzik de tüketime dayalı kitle kültürü dolayısıyla bir endüstriye dönüşmüştür. Medya bu değişimi hızlandıran ve yapısallaştıran bir etki üretmektedir.

\section{Kaynakça}

Adorno, W. Theodor. “On Popular Music”. Studies in Philosophy and Social Science. New York: Institute of Social Research, 9 (1941).

Ak, Şahin. Avrupa ve Türk İslam Medeniyetinde Müzikle Tedavi Tarihi Gelişim ve Uygulamaları. Konya: Öz Eğitim Yayınevi, 1997.

Akan, Nesrin. Platon'da Müzik. İstanbul: Bağlam Yayıncılık, İkinci Basım, 2017.

Apaydın, Ayna İsababayeva ve Fazlı Arslan. "Antik Yunan Felsefesinde Ahlaki Eğitim Aracı Olarak Müzik”. Değerler Eğitimi Dergisi. 29-Ek-Özel/13 (2015): 323-342.

Arapgirlioğlu, Hasan. "Dünyada ve Türkiyede Müzik Endüstrisinin Dünü, Bugünü ve Yarını”. içinde Yaratıcı Endüstriler Uluslararası Tasarım Sempozyumu (01-02 Haziran 2016) Bildiriler Kitabı. Ed. Mehmet Emin Kahraman. İstanbul: Yildız Teknik Üniversitesi Basım-Yayın Merkezi, 2016.

Aydoğan, Filiz. “Popüler Kültür ve Popüler Müzik”. İstanbul Üniversitesi İletişim Fakültesi Dergisi. 20 (2004): 207-213.

Balamir, Ebru. “Commedia Dell'arte, Tiplemeler ve Carlo Goldonı ile İtalyada Tiyatro Reformu”. Rumeli de Dil ve Edebiyat Araştırmaları Dergisi. 9 (2017): 81-88.

Campell, Don. Mozart Etkisi. Çev. Feryal Çubukçu. İstanbul: Kuraldışı Yayıncılık, 2002.

Çiftçi, Ersan. "Popular Culture, Populer Music and Music Education”. Erzincan Eğitim Fakültesi Dergisi. 12/2 (2010): 149-161.

Çuhadar, C. Hakan. "Müziksel Zeka” Ulusal Müzik Eğitimi Sempozyumunda Sunulan Bildiri, Pamukkale Üniversitesi Eğitim Fakültesi, Denizli, Nisan 26-28, 2006.

Çüçen, A. Kadir. "Batı Aydınlanmasının Düşünsel Kökenleri ve Eleştirisi”, Muğla Üniversitesi Sosyal Bilimler Enstitüsü Dergisi (İLKE). Atatürk'ün Doğumunun 125. Yılı ve Cumhuriyetimizin 83. Y1lı Özel Sayısı, 2006.

Doğan, Tekin ve Barış Erdal. “Senin Favori Çalgın Hangisi? Çalgı Tercihini Etkileyen Demografik ve Sosyo-Kültürel Faktörler Üzerine Bir Araştırma”. Journal of Human Sciences. 13/3 (2016).

Gardner, Howard. Zihin Çerçeveleri, Çoklu Zeka Kuramı. Çev. Ebru Kılıç. İstanbul: Alfa Yayınları, 3. Baskı, 2017. 
Gedikli, Erdem. Müzik Eğitimi. Bursa: Ezgi Kitabevi, 2003.

Goldman, Jonathan. Seslerin Gizli Gücü. İstanbul: Sınır Ötesi Yayınları, 2010.

Göher, M. Feyzan. "Müziğin Toplumsal İşlevi Müzik, Siyaset, Din ve Ekonomi”. 38.

ICANAS (International Congress of Asian and North African Studies - Uluslararasi Asya ve Kuzey Afrika Çalışmaları Kongresi, Ankara, Eylül 10-15, 2007) Ankara: Atatürk Kültür Dil ve Tarih Yüksek Kurumu Yayınları 9, I. Cilt, 2009.

İnan, Abdülkadir. Tarihte ve Bugün Şamanizm. Ankara: Türk Tarih Kurumu Basimevi, 1986.

İngev (İnsani Gelişme Vakfı). “İnsani Gelişme Nedir?”. İngev (İnsani Gelişme Vakfı). Erişim 12 Nisan, 2018. http://ingev.org/hakkimizda/insani-gelisme-nedir/

Kapani, Münci. Politika Bilimine Giriş. Ankara: Bilgi Yayınevi, 2008.

Karamızrak, Neslihan. "Ses ve Müziğin Organları İyileştirici Etkisi”. Koşuyolu Heart Journal. 17(1), 2014.

Kaya, Deniz. "Johann Sebastian Bach'ın "Füg Formları"nın ve "Füg Sanatı" Adlı Eserinin Barok Dönem Müzik Anlayışına Göre İncelenmesi”. Yüksek Lisans Tezi, Çukurova Üniversitesi, 2009.

Kılıç, Fahri. "Çok Sesli Batı Müziğinin Türk Modernleşmesindeki Önemi”. 38. ICANAS (International Congress of Asian and North African Studies - Uluslararası Asya ve Kuzey Afrika Çalışmaları Kongresi, Ankara, Eylül 10-15, 2007). Ankara: Atatürk Kültür Dil ve Tarih Yüksek Kurumu Yayınlar1 9, I. Cilt, 2009.

Kılıç, Tuba. "Müziğin Kişisel, Toplumsal, Ulusal Ve Uluslararası İşlevlerinin Müzik Eğitimine Etkileri”. 38. ICANAS (International Congress of Asian and North African Studies - Uluslararası Asya ve Kuzey Afrika Çalışmaları Kongresi, Ankara, Eylül 10-15, 2007) Ankara: Atatürk Kültür Dil ve Tarih Yüksek Kurumu Yayınları. 9, I. Cilt, 2009.

Kitirci, Bensu. "Palyatif Bakım Ünitelerinde Uygulanan Müzik Terapi Çalışmaları Üzerine Bir Araştırma”. Afyon Kocatepe Üniversitesi Akademik Müzik Araştırmaları Dergisi (AMADER). IV / 8 (2018).

Mırak, Dilan ve Özgür Temiz. "Hukuk ve Politika Türkiye'de Yaşanan Olağanüstü Dönemlerin Edebiyat Eserleri Işı̆̆ında İncelenmesi”. Ankara Barosu Dergisi. 67/2 (2009): 77-97.

Odabaşı, Fatma. "Dil-Kültür Bağlamında Müzik Dili Ve Bunun Sosyal Bütünleşmedeki Yeri”. İstanbul Üniversitesi İlahiyat Fakültesi Dergisi. 14 (2006): 237-258.

Önal, Özay. “Ses, Dil ve Müzik”. Dil Dergisi. 155 (2012): 7-23.

Özeren, Alp. "Çocuklar İçin Yaratılan Müzik Yapıtlarının Toplumsal Müzik Bilinci ve Dil Gelişimi Açısından Rolü ve Önemi”, II. Ulusal Çocuk ve Gençlik Edebiyatı Sempozyumunda Sunulan Bildiri, Ankara Üniversitesi Eğitim Bilimleri Fakültesi, Ekim 04-06, 2006.

Özkan, Abdullah. Siyasal İletişim. İstanbul: Nesil Yayınları, 2004.

Paçacı, İrfan. Küreselleşme Sürecinde Yönetim ve Medyanın Dönüşümü. İstanbul: Akademi Titiz Yayınları, 2013.

Peretz, Isabelle ve Robert J. Zatorre, "Brain Organization for Music Processing". 
Annual Review of Psychology. 56/1 (2005).

Platon. Devlet. Çev. Cem Taşkıran. Ankara: Pan Kitapevi Yayınları, 2005.

Raphael, David Daiches. Problems of Political Philosophy, London: Macmillan Education Ltd., Second Edition, 1990.

Sanatteorisi.com. "Çoksesli Müzik ve Topluma Etkileri”. Erişim $27 \quad$ Nisan, 2018. http://www.sanatteorisi.com/sanatteorisi. asp? sayfa $=$ Makaleler\&icerik= Goster\&id=2719

Sapancalı, Faruk. Toplumsal Açıdan Yaşam Kalitesi. İzmir: Altın Nokta Yayınları, 2010 .

Sazak, Nilgün. “Müziksel Algılamanın Temel Boyutları”. Uluslararası İnsan Bilimleri Dergisi. 5/1 (2008): 1-11.

Smith, Adam. Milletlerin Zenginliği. Çev. Haldun Derin. İstanbul: İş Bankası Kültür Yayınları, 2016.

Somakcı, Pınar. “Türklerde Müzikle Tedavi”. Sosyal Bilimler Enstitüsü Dergisi. 15 (2003): 131-140.

Srinivasan, T. N. "İnsani Gelişme Yeni Bir Paradigma mı, Yoksa Tekerleğin Yeniden İcadı mı”. Çev. Şenay Sezgin Nartgün. Ankara Üniversitesi Eğitim Bilimleri Fakültesi, Dergisi. Say1: 1, Cilt: 32 (2007): 238-243.

Tekeli, İlhan. Gündelik Yaşam, Yaşam Kalitesi ve Yerellik Yazıları. İstanbul: Tarih Vakfı Yurt Yayınları, 2010.

The Economist. "Where The Living is Easier". Erişim 2 Mart, 2018. http://www. economist.com/blogs/graphicdetail/2012/03/daily-chart-8? zid=292\&ah= 165a5788fdb0726c01b1374d8e1ea285

Timisi, Ali Haydar. “Müzik Nedir”. Erişim 17 Ağustos, 2018. http://www.timisi.com/ blog/2017/10/30/muzik-nedir/

Tiyatro Dünyası. "Commedia Dell Arte”. 22 Nisan 2007. Erişim 27 Nisan, 2018. http://www.tiyatrodunyasi.com/2007/04/commedia-dell-arte-56283

Turkcebilgi.com. "Müzik". Erişim 27 Nisan, 2018. https://www.turkcebilgi.com/ m\%C3\%BCzik

Wikipedia. “Müzik”. Erişim 27 Ocak, 2018. http://tr.wikipedia.org/wiki/ M\%C3\%BCzik

Yurga, Cemal. 20. Yüzyılda Türkiye’de Popüler Müzikler. Ankara: Pegema Yayınc1lık, 2002 . 
İNSAN\&İNSAN, Y11/Year 6, Say1/Issue 21, Yaz/Summer 2019, 691-712

DOI: https://doi.org/10.29224/insanveinsan.505323

\title{
Music and Politics: Interactional Cooperation of Emotion and Thought İRFAN PAÇACI
}

\begin{abstract}
Music is one of the areas in which the emotion and thought which have constituted the common cultural heritage of humanity that led to the development of "communion and interactive cooperation" and it is also a field of act uniting peace and freedom. However, music has functions that go beyond this function. Compliance, cooperation, harmony, reconciliation, cooperation of mind and emotion is a field of activity for keeping the common values, whereby material and meaning are produced together, and embodied as words and melodies. It has common features with politics, which is another social activity with these characteristics. Music and politics, which are among the requirements of the democratic society in contemporary states, have the potential to be two important catalysts in the development of society beyond forming a cultural indicator. Both are the areas in which the functional and cultural materials of cooperation and harmony are produced and brought into social life. The basic hypothesis of this study is that music and politics contribute positively to the survival and development of democracy.
\end{abstract}

Keywords: Music, Politics, Democracy, Interactional cooperation. 